\title{
Scenariji budućnosti - afektivne i kognitivne reakcije ljudi na informacije o budućnosti i tehničkom razvoju
}

\author{
Eva Jurković \\ Sirius - Centar za psihološko savjetovanje, edukaciju i istraživanje, Zagreb, Hrvatska \\ Dragutin Ivanec \\ Sveučilište u Zagrebu, Filozofski fakultet, Odsjek za psihologiju, \\ Zagreb, Hrvatska
}

\begin{abstract}
Sažetak
Cilj je istraživanja bio ispitati kognitivne i afektivne reakcije ljudi na informacije o vrlo brzom tehničkom razvoju koji će se, sukladno Mooreovu zakonu o eksponencijalnom razvitku tehnike i predviđanjima stručnjaka za računalne znanosti, u bliskoj budućnosti još više ubrzati i proširiti na sve domene ljudskog života. Pitanje je koliko su ljudi spremni na te promjene i kako bi ih mogli prihvaćati ili odbijati, kako s afektivnog, tako i kognitivnog aspekta. U istraživanju su sudjelovale tri skupine sudionika $(N=197)$. Prva je kroz planirano predavanje dobila informacije o budućnosti tehničkog razvoja, koje su se temeljile na znanstvenim predviđanjima i promišljanjima autoriteta. Druga je skupina dobila implicitne informacije o mogućim promjenama kroz prikazivanje jednoga znanstvenofantastičnog filma. Treća je skupina bila referentna, odnosno nije dobila nikakve informacije. Kod prvih dviju skupina prikupljeni su podaci o afektu prije i poslije predavanja/filma, a kod sve tri skupine prikupljeni su podaci o percepciji budućnosti te percepciji pozitivnosti napretka. Rezultati su pokazali da su skupine koje su bile izložene informacijama o budućnosti sustavno procjenjivale budućnost negativnije nego referentna skupina. Te su razlike bile statistički značajne, ali relativno male. Pokazalo se da su i neke stabilne karakteristike iz domena ličnosti, poput optimizma i dimenzije intelekta, bile blago pozitivno povezane s percepcijom budućnosti. Rezultati impliciraju na važnost pokretanja interdisciplinarnih akademskih rasprava o mogućim utjecajima brzog razvoja tehnike na život ljudi kako bismo olakšali prilagodbu ljudi na brz razvoj koji nam predstoji.
\end{abstract}

Ključne riječi: tehnologija, budućnost, razvoj, napredak

\section{Uvod}

Živimo u užurbanom vremenu u kojem smo svakodnevno preplavljeni novim i poboljšanim tehničkim izumima. Vijek proizvoda postao je znatno kraći od ljudskog

Eva Jurković, Sirius - Centar za psihološko savjetovanje, edukaciju i istraživanje, Bužanova ul. 10, 10000 Zagreb, Hrvatska. E-pošta: eva.jurkovic@ gmail.com 
vijeka te se unutar jedne ljudske generacije izmjeni veći broj tehničkih razdoblja, a svako od njih donosi velike novine i životne promjene na koje se kao vrsta kontinuirano trebamo prilagođavati. Tehnički razvoj općenito pokazuje obrazac eksponencijalnog razvoja. O tome nam govori Mooreov zakon (1965; prema Schaller, 1997), koji kaže kako se maksimalni broj čipova u tranzistoru (a sukladno tome i snaga računala) udvostručava otprilike svake dvije godine. Drugim riječima, to znači da otprilike svake dvije godine razvijamo dvostruko bolju tehniku (računala, mobitele, robote, medicinska pomagala, slikovne prikaze mozga, itd.). Kurzweil (2005) u svojoj knjizi The singularity is near predviđa kako će, prema izračunu eksponencijalnog rasta, ukupan napredak u 21. stoljeću biti čak 1000 puta veći od ukupnog napretka 20. stoljeća. Prisjetimo li se samo nekih tehničkih otkrića 20. stoljeća: automobila, autocesta, zrakoplova, elektronike, radija, televizije, računala, interneta, svemirskih misija, nuklearne energije - možemo li uopće zamisliti što znači 1000 puta veći tehnički razvoj od ukupnog postignutog u 20. stoljeću? Do sada se čovječanstvo prilično uspješno nosilo s promjenama koje su nove tehnike donosile. Hoće li tako biti i u budućnosti?

Značajne izazove za prilagodbu ljudi osobito će predstavljati razvoj robotike, umjetne inteligencije i poboljšanja ljudi tehnikom. Što se tiče robotike, predviđanja upućuju na to kako bi roboti mogli postati sve zastupljeniji u svim područjima ljudskih života, kako u privatnosti vlastitih domova, tako i na široj razini, u industrijskog proizvodnji (Bar-Cohen i Hanson, 2009). Nedavno provedena ekonomska analiza Merrila Lyncha (2015; prema Stewart, 2015) predviđa da će u sljedećih 20 godina oko $50 \%$ poslova koje trenutno obavljaju ljudi moći biti zamijenjeno robotima. Teško je zamisliti kakve bi tek implikacije za život ljudi mogao imati razvoj umjetne inteligencije na razini ljudske. Transhumanisti smatraju kako bismo se pomoću tehnike trebali poboljšati da bismo se mogli nositi $\mathrm{s}$ posljedicama koje nam je upravo radikalni razvoj tehnike i drugih znanstvenih spoznaja donio (Persson i Savulescu, 2012; Selak, 2013). Transhumanistički pokušaji poboljšanja ljudi nužno nameću pitanje zadiranja u ljudsku prirodu u najširem smislu, od biološkog do socio-psihološkog. Intrigantno je kakve bi posljedice takve promjene mogle imati na ljude i cjelokupnu prirodu. Stoga je relevantno pitanje o potencijalnoj spremnosti ljudi za prihvaćanje takvih promjena, ali i posljedica tih promjena. Važno je i kako ljudi, od stručnjaka, ali i opće populacije, formiraju percepciju o budućnosti i brzim promjenama koje ona nosi.

Iako se ove izuzetne promjene u svijetu tehnike zaista događaju te se intenzivno radi na razvijanju svih ovih područja, a najveće svjetske tvrtke najveću količinu novca ulažu upravo u svrhu stvaranja umjetne inteligencije, mnogi ljudi uopće nisu upućeni u to što se događa. U medijima i javnosti relativno se malo pažnje posvećuje raspravi o ovim temama te je ona nesustavno obrađena. Ovim bi se temama trebalo pristupiti sustavno jer je budućnost to što nas očekuje, i trebali bismo, pogotovo sada, u vrijeme do sada najbržega tehničkog napretka u povijesti čovječanstva, razmišljati i više govoriti o tome, tj. sudjelovati u stvaranju budućnosti. Je li pretpostavljeni 
tehnički napredak prirodan ili neprirodan, dobar ili loš, u ovom je trenutku manje važno, jer je malo vjerojatno da će se on zaustaviti. Na razvoj superinteligencije, koja bi u shvaćanju vlastite prirode mogla biti sposobnija od nas, može se gledati kao na prirodan nastavak ljudske vrste, kao sljedeću razinu u našem evolucijskom razvoju. Ali i ne mora. Predviđanja budućnosti vrlo su kompleksna, stoga i nepouzdana. Primjerice, umjetna superinteligencija predviđa se od samih početaka razvoja umjetne inteligencije polovicom 20. stoljeća, a njezin se očekivani dolazak opetovano pomiče dvadesetak godina u budućnost. Ipak, znatne promjene u budućnosti uzrokovane sve bržim tehničkim razvojem sigurno će se događati. Do razvoja umjetne inteligencije na razini ljudske može i ne mora doći, no vrlo vjerojatno roboti će zbog svoje efikasnosti postati sve zastupljeniji u industrijskim i uslužnim djelatnostima, a takve će promjene imati velik utjecaj na život svih ljudi.

Potencijalni je učinak vrlo brzog razvoja modernih tehnika na psihološko funkcioniranje ljudi pitanje koje je važno kako teorijski, tako i praktično. Velika većina populacije zapravo nije toliko osviještena glede promjena u relativno bliskoj budućnosti koje nosi vrlo brz tehnički razvoj, a koji je, kako je navedeno, eksponencijalan. Istina, ljudski rod se "suočavao" i u zadnjih nekoliko desetljeća s brzim napretkom i prilagodbom novim tehničkim rješenjima proizašlih iz napretka. I ta je prilagodba bila uspješna, odnosno bez većih poteškoća za ljudsko funkcioniranje na svim razinama. No, valja se sjetiti glavne značajke eksponencijalnog razvitka, a to je izrazito ubrzavanje - napredak koji nam predstoji mogao bi biti značajno brži i dramatičniji na svim razinama ljudskog funkcioniranja, te bi prilagodba utoliko mogla biti izazovnija.

Postavlja se pitanje percipiraju li ljudi i danas potencijalne promjene kao normalne, poželjne, dobrodošle, ili, pak, uznemirujuće, pa i štetne po svijet u kome živimo. Zaziru li ljudi od potencijalne umjetne inteligencije koja bi nas mogla "prevladati" i zagospodariti ljudima ili je to tek dio procesa na koji ljudi gledaju kao čovjekovo nastojanje neprestanog prilagođavanja svoje okoline (pa i sebe samih) što jednostavnijoj i lakšoj egzistenciji? Ova su pitanja vjerojatno prisutna kroz cijelo vrijeme moderne ljudske povijesti, ali su u 21. stoljeću dodatno i posebno dobila na važnosti.

Percepcija budućnosti povezana je s očekivanjima te budućnosti. Očekivanja nekog ishoda i vjerojatnost budućih događaja važna je odrednica trenutnog ponašanja (Kirsch, 1985; Peerdeman, van Laarhoven, Peters i Evers, 2016). Očekivanje svoje djelovanje na ponašanje i doživljavanje ostvaruje u cijelom rasponu, od jednostavnih procesa kod osjeta pa do složenijih kognitivnih funkcija, i slobodno se može reći da je djelovanje očekivanja sveprisutno (Bar, 2007; Schwarz, Pfister i Büchel, 2016). Ovisno o specifičnom kontekstu u kojem se stvaraju predviđanja očekivanja su o toj budućnosti više ili manje jasna, ili jednoznačna. Adaptivno ponašanje implicira da smo neprestano okrenuti budućnosti, kako bliskoj, tako i onoj daljoj (Bubić i Abraham, 2014). Jedino ako ćemo razumjeti takve procese, možemo razumjeti i procese koji su u osnovi evolucije prilagodljivog uma (Pezzulo, 
Hoffmann i Falcone, 2007). Očekivanja mogu imati različite forme, poput izjava o budućnosti koje cirkuliraju u nekoj populaciji (izgovorene ili upisane u tekstove ili materijale) (Van Lente, 2012). Očekivanja ili vizije budućnosti mogu biti pozitivne ili negativne, a možemo ih razlikovati i po apstraktnosti ili specifičnosti/općenitosti (Konrad, 2006). U sadržajnom smislu to mogu biti očekivanja od razvoja tehnike, komercijalnog ponašanja i društvenih aspekata funkcioniranja ljudi. Očekivanja $s$ kojima ljudi gledaju u budućnost mogu biti ona koja su formirana intuitivno, bez previše analiziranja informacija na kojima su nastala pa do očekivanja koja su plod detaljno organiziranih argumenata na temelju kojih se dolazi do zaključaka. Zajedno s pozitivnim očekivanjima i nadama o budućnosti, dio dinamike očekivanja čine i strahovi i brige oko potencijalnih rizika (Borup, Brown, Konrad i van Lente, 2006). A to su osnove koje mogu biti odrednica poželjnosti i pozitivnosti tehničke promjene.

Imajući u vidu važnu ulogu koju očekivanja vezana uz potencijalnu budućnost mogu imati u daljnjem razvoju tehnike, zanimljivo je osvrnuti se na ulogu prezentiranja informacija na formiranje očekivanja o toj budućnosti. Dok je kod postojećih tehničkih rješenja korisnikovo mišljenje formirano kroz direktno iskustvo, kod budućih tehničkih rješenja korisnikov zaključak o prihvatljivosti, korisnosti i pozitivnosti nove tehnike temeljen je na načinu na koji je ona reprezentirana. Mancini i sur. (2010) istraživali su različite reakcije ljudi na novu tehniku, pri čemu su jednoj skupini u prezentacijskom videu više naglasili pozitivne aspekte nove tehnike, a u drugoj su se u videu više usmjerili na njezine negativne aspekte. Oba su videa potaknula brojna promišljanja i brige kod sudionika istraživanja, no brige su bile različitog sadržaja u dvije skupine. Autori zaključuju kako korisnici dublje promišljaju o mogućim posljedicama nekog izuma kad imaju priliku vidjeti i njegove potencijalne koristi i mane, te se zalažu za dvostruku reprezentaciju kontroverzinih novih tehnika. Potrebno je ukazati na pozitivne aspekte, no jednako tako korisnike potaknuti da promišljaju i o mogućim negativnim efektima novih izuma.

Ovi nalazi upućuju na potencijalnu važnost načina na koji se budućnost tehničkog razvoja prikazuje široj populaciji. Danas je najrasprostranjeniji način prikazivanja potencijalne budućnosti znanstvenofantastičnim filmovima, koji uglavnom prikazuju distopijsku viziju budućnosti, a intrigantno je promišljati je li ovaj način prikazivanja tehničkog razvitka pozitivan za naš boljitak i je li potreban i paralelni znanstveno utemeljen način kolektivnog promišljanja o budućnosti tehničkog razvoja, koji bi uravnoteženo prikazivao potencijalne pozitivne i negativne aspekte razvoja. 


\section{Cilj istraživanja}

Pitanja na koja se nastoji odgovoriti ovim istraživanjem je kako ljudi reagiraju kada su izloženi informacijama o trenutnim dosezima i predviđanjima relativno bliske budućnosti o planiranom razvoju u područjima robotike, umjetne inteligencije i transhumanizma. Percepcija budućih promjena može imati temelje u predviđanjima stručnjaka koji se intenzivno bave robotikom, umjetnom inteligencijom i transhumanizmom. Ali mogu biti prikazane i na jednoj općenitijoj razini, s manjim znanstvenim kredibilitetom, odnosno takve da nisu jasno i specifično povezane $\mathrm{s}$ konkretnim razvojem tehnike. Pitanje u kojoj mjeri informacije različitog sadržaja i forme mogu biti povezane s percepcijom budućnosti, kako na afektivnoj, tako i na kognitivnoj razini od interesa je i na znanstvenoj i na društvenoj razini.

Ovo je istraživanje primarno ekploratornog karaktera, bez jasnih smjernica iz prijašnjih istraživanja, jer takvih zapravo nema. Stoga se ni očekivanja ishoda ne mogu jasno predvidjeti. Jedan smjer predviđanja može ići iz evolucijske perspektive, tj. sklonosti ljudi da se iz skupa informacija više usmjeravaju na one negativne (Rozin i Royzman, 2001; Skowronski i Carlston, 1989) te se može očekivati da će one imati veći učinak na formiranje percepcije budućnosti i napretka. Može se očekivati povećanje razine negativnog afekta te negativnije percepcije budućnosti i napretka kod sudionika koji će biti suočeni s predviđanjima tehničkog razvoja u kontekstu realnih scenarija budućnosti, a koji naglašavaju brze i značajne promjene. Takve informacije mogu potaknuti sumnje u vlastitu dobrobit. No, smjer može biti i obrnut: razina pozitivnog afekta i kognitivnih procjena također bi mogla porasti nakon dobivanja utemeljenih informacija jer razvoj tehnike redovito producira $\mathrm{i}$ mnoge pozitivne posljedice.

S druge, pak, strane, može se pretpostaviti da će nespecifično očekivanje budućih tehničkih promjena imati manje jasnih osnova, pa time dovoditi do slabijih reakcija ljudi. Promjene u afektivnim procjenama budućnosti ne očekuju se nakon informacija koje su po svojoj prirodi slične realnim odnosno znanstveno utemeljenim predviđanjima, ali su kvaziznanstvenog karaktera i ne odnose se na direktno i jasno predviđanje skorih promjena u budućnosti (npr. znanstvenofantastičnog prikaza budućnosti SF filmom). Pretpostavka je da tako prikazane informacije sudionici neće povezivati s realnim promjenama koje ih čekaju u budućnosti, te da će na takve informacije njihove reakcije (kako afektivne, tako i kognitivne) stoga biti slabije.

Odnos prema budućnosti mogao bi ovisiti i o nekim individualnim razlikama koje su u domeni ličnosti, kao što su sklonost optimizmu i pesimizmu te širim dimenzijama ličnosti. Optimizam i pesimizam općenito su očekivanja ljudi o pozitivnim ili negativnim ishodima aktivnosti u budućnosti, te logično slijedi da bi percepcija pozitivnosti budućnosti i napretka mogla ovisiti o izraženosti ovih osobina (Chang, 2001). Dimenzija intelekta, kao šira od optimizma, označava ljude koji su općenito kreativniji, skloniji nekonvencionalnim vjerovanjima, otvoreni prema avanturama, neobičnim idejama, raznovrsnosti iskustava (Goldberg, 1999). Takvi će 
ljudi vjerojatno imati pozitivnija očekivanja od budućnosti i pozitivniju percepciju napretka tehnike. Stoga bi i takvi podaci bili korisni u razumijevanju potencijalnog odnosa ljudi prema tehničkim promjenama, koje nas gotovo sigurno očekuju.

\section{Metoda}

\section{Nacrt istraživanja}

U istraživanju su sudjelovale tri neovisne skupine sudionika. Prvoj su skupini sudionika kroz pomno planirano predavanje prezentirane informacije o budućnosti tehničkog razvoja. Te su informacije odabrane na temelju relevantnih znanstvenih podataka te argumentacije i promišljanja eksperata tehničkog i računalnog napretka o tome kako bi budućnost tehničkog razvoja mogla izgledati. Drugoj je skupini sudionika bio prikazan znanstvenofantastični prikaz budućnosti, ali na temelju uobičajenih filmskih ideja koje nemaju težinu točne i znanstveno plauzibilne predikcije razvoja u budućnosti. Treću je skupinu sačinjavao uzorak ispitan internetom te su njihove procjene imale status referentnih podataka (bez davanja ikakvih informacija o promjenama u budućnosti). Kod prve i druge skupine prikupljani su podaci prije i poslije davanja informacija o mogućim promjenama $\mathrm{u}$ skoroj budućnosti. Nacrt je shematski prikazan u Tablici 1.

Tablica 1.

Shematski prikaz nacrta istraživanja i postupka prikupljanja podataka

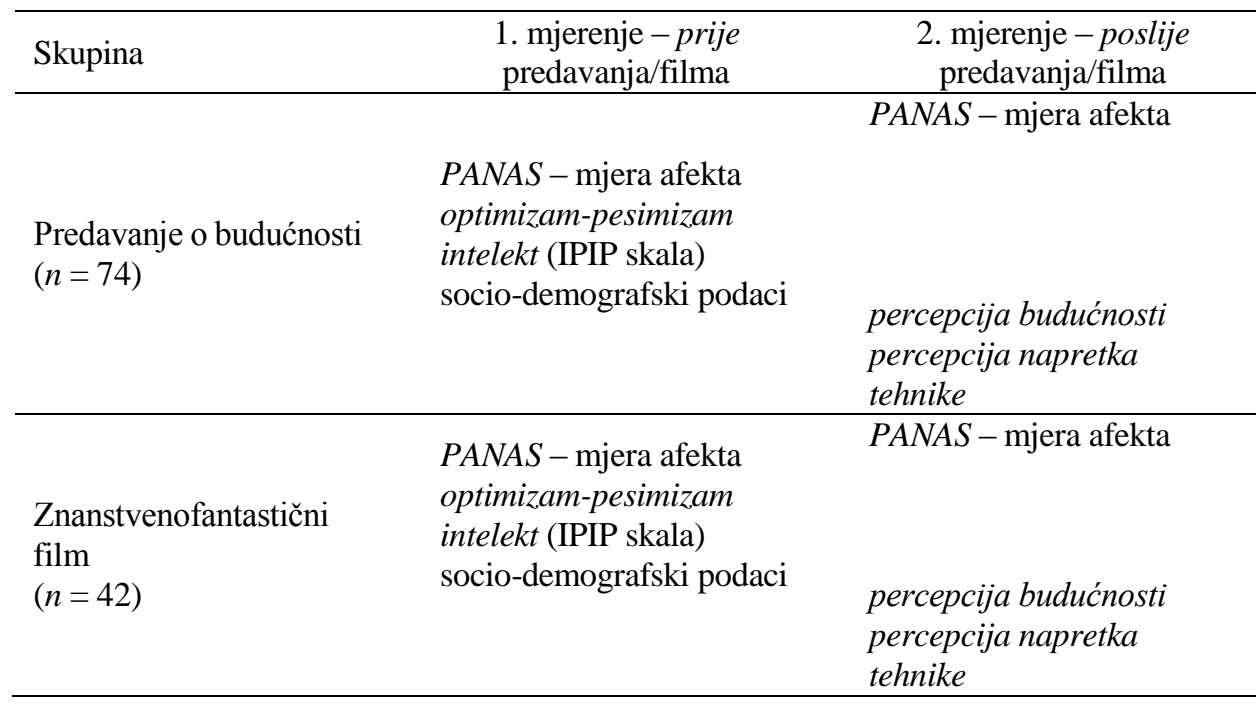




\begin{tabular}{lll}
\hline Skupina & \multicolumn{1}{c}{$\begin{array}{c}\text { 1. mjerenje-prije } \\
\text { predavanja/filma }\end{array}$} & $\begin{array}{c}\text { 2. mjerenje - poslije } \\
\text { predavanja/filma }\end{array}$ \\
\hline & $\begin{array}{l}\text { optimizam-pesimizam } \\
\text { intelekt } \text { (IPIP skala) }\end{array}$ & \\
Komparabilna skupina & percepcija budućnosti \\
(internetska anketa) & $\begin{array}{l}\text { percepcija napretka } \\
\text { tehnike } \\
\text { socio-demografski podaci }\end{array}$ & \\
&
\end{tabular}

\section{Korištene psihološke mjere}

Skala pozitivnog $i$ negativnog afekta (engl. Positive and Negative Affect Schedule, PANAS; Watson i Clark, 1988) daje nam informaciju o razini dvije dimenzije afekta - pozitivnog (PA) i negativnog (NA). Pokazalo se da skala ima visoku pouzdanost i konstruktnu valjanost te da su dva faktora relativno nezavisni, no nisu u potpunosti ortogonalni - postoji umjerena negativna korelacija između ovih dvaju faktora (Crawford i Henry, 2004). Razina zajedničke varijance latentnih faktora PA i NA u istraživanju Crawforda i Henryja iznosila je 9\%. Osobe s visokim PA pune su entuzijazma, energije i optimizma, a osobe s niskim PA letargične su, apatične i često im je dosadno. Osobe s visokim rezultatom na NA tipično su nezadovoljni, nervozni i razdražljivi dok su oni s niskim NA smireni i opušteni. PANAS-om se mogu mjeriti neke stabilne individualne karakteristike u afektivnom iskustvu, ali pokazalo se da rezultati variraju i ovisno o vanjskim varijablama, kao što su društvena aktivnost (Watson, 2000) ili prestanak pušenja (Perkins, Karelitz, Conklin, Sayette i Giedgowd, 2010). Skala sadrži 20 čestica, pri čemu 10 mjeri PA (npr. snažno, zainteresirano, nadahnuto), a 10 NA (npr. razdražljivo, nervozno, uplašeno). U ovom istraživanju pouzdanost tipa unutarnje konzistencije za PA iznosi $\alpha=.84$, a za NA $\alpha=.87$.

Skala optimizma/pesimizma (OP skala; Penezić, 2002) korištena je kako bismo dobili informaciju o općenitom očekivanju sudionika o pozitivnim ili negativnim ishodima aktivnosti u budućnosti. Optimizam i pesimizam neki autori shvaćaju kao relativno nezavisne osobine (Herzberg, Glaesmer i Hoyer, 2006; Zuckerman, 2003) i stabilne dimenzije ličnosti, pri čemu je njihova definicija orijentirana na očekivanja pozitivnih i negativnih ishoda budućih događaja. $U$ hrvatski prijevod skale autora Changa (Chang, Maydeu-Olivares i D'Zurilla, 1997) uvršteno je 14 tvrdnji: šest za procjenu optimizma i osam za procjenu pesimizma. Prema istraživanju Penezić i sur. (1999; prema Penezić, 2002) skale su pokazale zadovoljavajući stupanj pouzdanosti tipa unutarnje konzistencije. U ovom istraživanju koeficijenti pouzdanosti tipa unutarnje konzistencije iznose $\alpha=.75$ za optimizam te $\alpha=.84$ za pesimizam.

Osobina intelekta za potrebe je ovog istraživanja mjerena dijelom Upitnika IPIP 50S (International Personality Item Pool 50S), tj. hrvatskom verzijom prijevoda Goldbergova (1999) upitnika IPIP, koji mjeri Velikih pet dimenzija ličnosti: ekstraverziju, ugodnost, emocionalnu stabilnost, savjesnost i intelekt (Mlačić i 
Goldberg, 2007). Iz upitnika je preuzeto 10 čestica koje mjere faktor intelekta. Usporediv s faktorom otvorenost iz Petofaktorskog modela, u modelu Velikih pet peti faktor naziva se intelekt ili kultura, a označavaju ga facete inteligentnosti, kreativnosti i sklonosti avanturizmu te liberalnost (Goldberg, 1999). Ljudi koji postižu visoke rezultate na ovim česticama tendiraju biti kreativniji, svjesniji vlastitih osjećaja te su skloniji imati nekonvencionalna vjerovanja. Otvoreni su prema umjetnosti, emocijama, avanturama, neobičnim idejama, mašti, znatiželji i raznovrsnosti iskustava. Intelektualno su znatiželjni te spremni isprobati nova iskustva. U ovom istraživanju pouzdanost tipa unutarnje konzistencije za dimenziju intelekta iznosi $\alpha=.79$.

Percepcija budućnosti u ovom je istraživanju procijenjena Skalom semantičkog diferencijala s 18 čestica od kojih svaka ima dva pola pri čemu jedan predstavlja pozitivna očekivanja od budućnosti, a drugi negativna. Primjeri su tih dihotomija: sreća-nesreća, red-kaos, sigurnost-opasnost itd. Uputa je sudionicima bila da za svaku od dihotomija označe jedan od brojeva na skali od 7 stupnjeva (od -3 do 3) uz onu riječ u paru koja je bliža njihovu poimanju budućnosti. Uputom je naglašeno kako je teško predviđati budućnost te kako nije bitno da njihova predviđanja budu točna, već da daju svoje mišljenje/predosjećaj o tome kakav će biti život 2050 . godine. Faktorskom analizom metodom glavnih komponenata dobivena je jednofaktorska struktura rezultata primijenjenih 18 čestica. Dvije čestice (prirodnoumjetno i zabava-dosada) nisu uzete u daljnju analizu jer se u faktorskoj analizi pokazalo da imaju niske korelacije sa zajedničkim faktorom. Ukupni je rezultat na skali izražen kao linearna kombinacija svih ostalih čestica, pri čemu polovi koji upućuju na pozitivno doživljavanje budućnosti imaju pozitivni, a polovi koji upućuju na negativna očekivanja negativni predznak. Teorijski raspon rezultata kreće se od 3 do 3. Pouzdanost tipa unutarnje konzistencije za skalu iznosi $\alpha=.94$.

Za ovo su istraživanje odabrana četiri pitanja kojima se htjelo dobiti informaciju o općoj percepciji sudionika o korisnosti i pozitivnosti tehničkog napretka. Kod sva je četiri pitanja skala odgovaranja bila od 1 do 5 , gdje je viša vrijednost značila pozitivniju percepciju napretka tehnike. Pitanja su bila: Hoće li tehnologija ${ }^{l}$ učiniti Vaš život boljim ili lošijim? (1 izrazito lošijim - 5 izuzetno boljim); Treba li nastojati zaustaviti razvoj tehnologije ili ga još više ubrzati? (1 zaustaviti - 5 znatno ubrzati); Koliko bi novaca države trebale ulagati u razvoj tehnologije? (1 ništa - 5 znatno više); Kakve će posljedice daljnji tehnološki napredak imati za čovječanstvo u cjelini? (1 izrazito loše - 5 izuzetno dobre). Postojale su pozitivne i umjereno visoke povezanosti između odgovora na ova četiri pitanja u svakoj skupini, faktorska analiza metodom zajedničkih komponenata upućuje na jedan zajednički faktor, a pouzdanost tipa unutarnje konzistencije iznosi $\alpha=.87$. Stoga je ukupan rezultat kreiran kao

\footnotetext{
${ }^{1}$ Iako je u ovom kontekstu terminološki, iz perspektive struke, korektnije upotrebljavati izraz tehnika nego tehnologija (tj. tehnički napredak umjesto tehnološki napredak), u istraživanju se sudionicima ipak pristupilo terminom tehnologija jer je on bliži svakodnevnom, uvriježenom izražavanju. Stoga se i u pozivu za sudionike koristio izraz tehnologija.
} 
linearna kombinacija pri čemu viši rezultat upućuje na pozitivniju percepciju napretka tehnike.

\section{Postupak}

Istraživanje je imalo eksperimentalnu manipulaciju koja se temeljila na davanju sudionicima dvije ponešto slične, ali i bitno različite informacije o bliskoj budućnosti. Prva je skupina (predavanje o budućnosti) predavanjem (predstavljeno kao tribina) dobila znanstveno relevantne informacije o budućnosti. Predavačica (prvi autor ovog rada) je sudionicima održala opširno izlaganje o stvarnim predviđanjima o razvoju tehnike u bliskoj budućnosti, s posebnim naglaskom na razvoj područja robotike, umjetne inteligencije i poboljšanja ljudi pomoću tehnike. Za predavanje su korištene realne znanstvene i tehničke informacije o trenutnom razvoju i znanstvena predviđanja u skoroj budućnosti koja su dali svjetski eksperti u tom području. ${ }^{2}$

U drugoj je skupini (znanstvena fantastika) sudionicima prikazan jedan znanstvenofantastični prikaz budućnosti, tj. jedna epizoda miniserije Black Mirror ${ }^{3}$. Prikazani se materijal ni na koji način nije povezivao sa stvarnim razvojem tehnike $\mathrm{u}$ budućnosti te o stvarnom razvoju tehnike ništa nije bilo spomenuto na tribini. Naglašeno je samo da kroz znanstvenofantastične priče dobivamo moralne heuristike za promišljanje o etičkim dilemama budućnosti.

Kod obje skupine (tribine) postupak je pomno planiran i proveden po točnoj određenoj formi. Sudionicima je naglašeno kako je riječ o istraživanju gdje se ispituje percepcija budućnosti. Također, priopćeno im je da nakon završetka tribine, odnosno projekcije neće biti rasprave o predstavljenim temama zbog kontrole u istraživanju, te da svoja mišljenja o budućnosti i napretku mogu dati u upitniku, koji je sadržavao i kvalitativni dio, nakon završetka tribine. Dvije su tribine održane jedna za drugom na Filozofskom fakultetu u Zagrebu. Tribina o budućnosti tehničkog razvoja održana je u 18 sati, a znanstvenofantastični prikaz slijedio je nakon toga, u 19:30 sati. Obje su tribine trajale oko sat vremena, pri čemu je predavanje/prikazivanje filma trajalo 45 minuta, a ispunjavanje upitnika dodatnih 15 minuta. Poziv za obje tribine bio je dan na jednak način, društvenim mrežama i oglasom na fakultetu, pod istim imenom (Scenariji budućnosti) i s jednakim pozivnim tekstom: Sudjelujte u zanimljivom istraživanju o budućnosti! Kroz tribinu propitujemo moguće scenarije budućnosti te kako će moderne tehnologije i njihov razvoj utjecati na život ljudi. Istraživanje

\footnotetext{
${ }^{2}$ Transkript cijelog tijeka postupka i tribina može se dodatno zatražiti od autora.

${ }^{3}$ Serijal Black Mirror sastoji se od zasebnih epizoda, a u sklopu svake se obrađuju etičke dileme koje bi se mogle pojaviti ako dođe do određenog izuma u budućnosti. U epizodi koja se prikazivala SF skupini (S2, E3: The entire history of you) istražuje se budućnost u kojoj je došlo do izuma uređaja koji snima cijeli naš život i omogućuje nam da si "premotamo" bilo koji trenutak svoje prošlosti, te su ga ljudi masovno počeli koristiti.
} 
uključuje i kratak upitnik u kojem ćemo Vas pitati za neka Vaša razmišljanja o budućnosti, tehnologiji i životu općenito.

Podaci prikupljeni internetskom anketom kod treće skupine bili su jednake forme kao i upitnici na tribinama, ali ispunjeni u jednom navratu te nisu sadržavali mjere afekta. Poziv za sudjelovanjem oglašavan je na društvenim mrežama i portalu forum.hr. Dvotjednom se istraživanju ukupno odazvalo 448 sudionika.

\section{Sudionici}

Većinu su sudionika (48\%) skupina na tribinama činili studenti psihologije, koji su zamoljeni za sudjelovanje $u$ istraživanju tijekom nastave pri čemu su im ponuđena dva potencijalna termina. Za sudjelovanje $u$ istraživanju studenti psihologije bili su nagrađeni eksperimentalnim satima, a dodatne su sate mogli zaraditi i dovodeći dodatne sudionike na istraživanje, koji nisu studenti psihologije. Time se nastojao dobiti raznovrsniji uzorak sudionika.

Kako je broj sudionika u komparabilnoj skupini bio značajno veći nego u preostale dvije, pri analizi rezultata iz te su skupine odabrani oni sudionici koji su prema nekim formalnim i sociodemografskim kriterijima bili najsličniji sudionicima s tribina. To su bili studenti od 18 do 24 godine, neoženjeni i bez djece. U konačnici je odabrani uzorak uključivao 81 sudionika u toj skupini. U sve tri skupine bio je otprilike jednak omjer muškaraca i žena (oko 30\% : 70\%). Oko 70-75\% sudionika u svim skupinama trenutno živi u velikom gradu (više od 500000 stanovnika).

Provedene su analize razlika među skupinama u varijablama koje bi mogle biti relevantne za percepcije budućnosti i napretka, kao što su: važnost vjere, optimizam, pesimizam, intelekt te opća razina pozitivnog i negativnog afekta. Pokazalo se da na svim mjerama nisu postojale početne razlike među skupinama (osim za varijablu optimizma, gdje je postojala statistički značajna razlika između komparabilne i skupine s filmom, u smjeru većeg optimizma u komparabilnoj $(M=3.78)$ nego u skupini s filmom $(M=3.48)(p=.02)$.

\section{Rezultati}

\section{Razlike u afektu prije i poslije izlaganja predavanju ili znanstvenofantastičnom filmu}

Kako bi se provjerilo dolazi li do promjena u pozitivnom i negativnom afektu ovisno o tome kojim su informacijama sudionici bili izloženi, provedene su dvije višesmjerne analize varijance za miješani nacrt, gdje je prvi faktor bila pripadnost skupini (znanstvene informacije ili znanstvenofantastični film), a drugi, u zavisnom nacrtu mjera afekta prije i poslije tretmana. Za obje su mjere afekta (pozitivnog i negativnog) rezultati statističke analize prikazani u Tablici 2. 
Tablica 2.

Rezultati višesmjerne analize varijance za mjere pozitivnog $i$ negativnog afekta kod dvije skupine koje su predavanjem ili znanstvenofantastičnim filmom dobile informacije o budućnosti

\begin{tabular}{lccc}
\hline Pozitivni afekt & $F$ & $p$ & $\eta_{\mathrm{p}}{ }^{2}$ \\
\hline prije-poslije izlaganju informacijama & 0.81 & .37 & \\
znanstvene informacije - zn. fantastični film & 1.01 & .32 & \\
interakcija & 7.84 & $\mathbf{. 0 0 6}$ & 0.06 \\
\hline Negativni afekt & & & \\
\hline prije-poslije izlaganju informacijama & 18.45 & $<.001$ & 0.14 \\
znanstveno predavanje - zn. fantastični film & 2.87 & .09 & \\
interakcija & 0.70 & .40 & \\
\hline
\end{tabular}

Smjer promjena $u$ razini mjera afekta uslijed izloženosti različitim informacijama o budućnosti prikazan je na Slici 1. Preciznosti interpretacije prikazanih odnosa doprinosi i analiza pojedinačnih razlika koje su u osnovi statistički značajne interakcije. Razlika u pozitivnom afektu prije dobivanja informacija između skupina ne postoji, dok je takva razlika statistički značajna nakon predavanja/filma $(p<.05)$. Nadalje, razlika između prvog i drugog mjerenja razine pozitivnog afekta nije statistički značajna kod skupine koja je gledala film, a jest kod skupine koja je dobila znanstveno utemeljene informacije o skorim budućim promjenama $(p<.01)$. Ukratko, iz Slike 1. vidi se da se pozitivni afekt promijenio na višu razinu, i to samo kod skupine koja je bila suočena s znanstvenim predviđanjima. Što se tiče negativnog afekta, opći je trend, što se vidi iz Slike 1., da je došlo do povećanja procjena i to kod obiju skupina. Pojedinačna testiranja pokazuju da su povećanja sustavna kod obiju skupina (kod skupine sa znanstvenim informacijama $p=.005$, a kod skupine koja je gledala znanstvenofantastični film $p=.02$ ). Ako se rezultati analiziraju zasebno za prvo procjenjivanje, odnosno zasebno za drugo, onda statistički značajne razlike između skupina ne postoje.
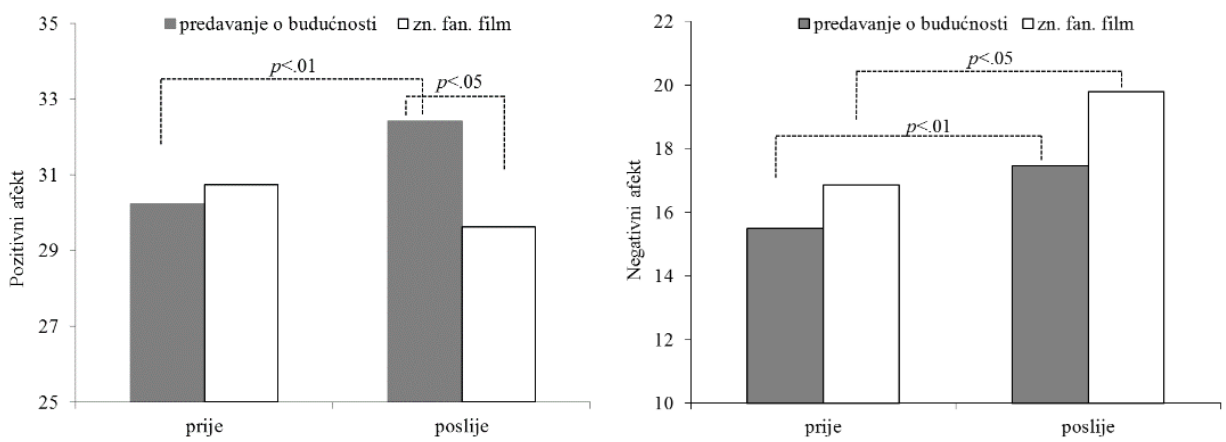

Slika 1. Promjene u mjerama pozitivnog i negativnog afekta ovisno o vrsti informacija koje su sudionici dobili na predavanju ili gledanjem filma. 


\section{Razlike među skupinama u skalama percepcije budućnosti i percepcije napretka}

Kako bi se provjerio učinak davanja različitih informacija na mjere percepcije budućnosti te percepcije napretka, testirana je statistička važnost razlike u prosječnom rezultatu na korištenim mjerama između triju skupina. Skupina kod koje su informacije prikupljene internetom (nije bila izložena informacijama eksperimentatora o budućnosti) tretirana je kao referentna. Analiza varijance pokazala je da postoji statistički značajna razlika između skupina i na mjeri percepcije budućnosti $\left(F(2,189)=4.34, p<.01, \eta_{\mathrm{p}}{ }^{2}=0.04\right)$, kao i na mjeri percepcije napretka $\left(F(2,192)=8.11, p<.01, \eta_{\mathrm{p}}^{2}=0.08\right)$. Odnosi među skupinama za obje mjere prikazani su na Slici 2. Naknadna su testiranja Schefféovim testom pokazala da u slučaju percepcije budućnosti postoji statistički značajna razlika između referentne skupine i skupine koja je dobila znanstvene informacije $(p<.05)$, dok razlika između referentne i skupine i one koja je gledala znanstvenofantastični film nije bila statistički značajna (iako je blizu razine statističke značajnosti $p=.085$ ). U slučaju percepcije napretka postojala je statistički značajna razlika komparabilne skupine prema ostalim dvjema (komparabilna - znanstvene informacije $p<.05$, komparabilna znanstvenofantastični film $p<.01$ ), dok između dviju grupa koje su dobile neke informacije razlike nije bilo. Rezultati pokazuju da su skupine kojima su bile dane informacije o tehničkom napretku u odnosu na referentnu skupinu iskazale negativniju percepciju te negativnija očekivanja od budućnosti i napretka koji ta budućnost nosi. Iako sve razlike nisu velike (veličine učinka relativno su male), one su međusobno sukladne. Percepcija budućnosti, koja bi se u ovom slučaju najbolje mogla poistovjetiti sa stavovima prema skoroj budućnosti tehničkog razvoja kod dviju skupina koje su dobile informacije o skorašnjoj budućnosti, pokazuje u prosjeku negativne stavove, a referentna pozitivne, dok je percepcija napretka kod te dvije skupine opet najmanje pozitivna.
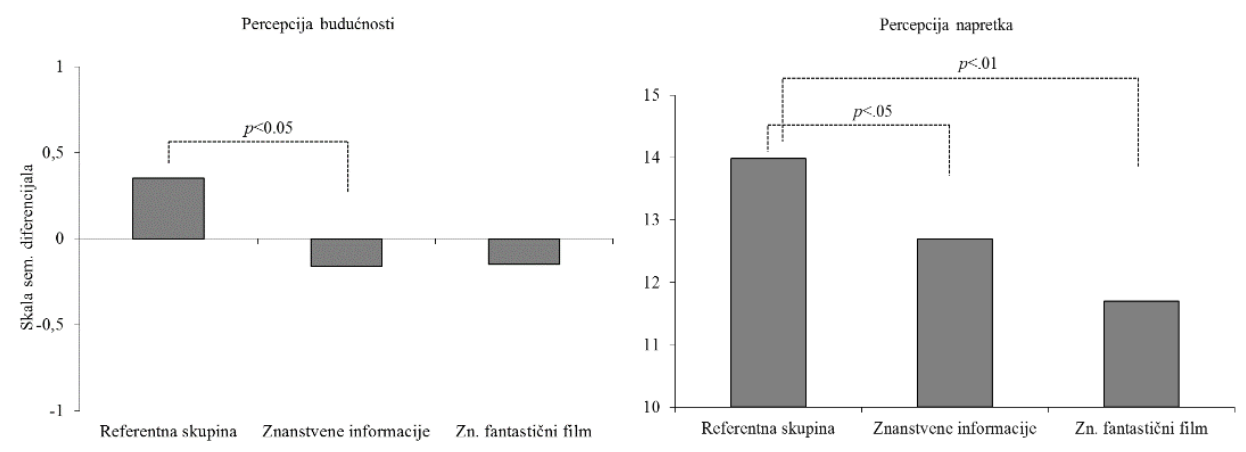

Slika 2. Razlike između triju skupina za percepciju budućnosti (skale semantičkog diferencijala gdje je nula neutralna vrijednost, a teoretski raspon je od -3 do 3) i percepciju napretka (mjerena četirima pitanjima, a raspon je od 4 do 20). 
Kako bismo provjerili moguću vezu promjene afekta zbog manipulacije i rezultata na mjerama percepcije budućnosti, izračunali smo njihovu povezanost. Postojala je povezanost jedino promjena $u$ negativnom afektu i percepcije pozitivnosti napretka: kod skupine koja je imala predavanje $r(74)=-.33, p<.01$, a kod skupine koja je gledala film $r(42)=-.44 ; p<.01)$. Veće promjene negativnog afekta prate manje pozitivne procjene pozitivnosti napretka.

\section{Ličnost i percepcija budućnosti}

Bivarijatni odnosi između crta ličnosti i mjera koje se referiraju na percepciju budućnosti i tehničkog napretka prikazani su u Tablici 3. Tri su mjere ličnosti nisko do umjereno povezane s dvije mjere percepcije budućih događaja. Pesimizam očekivano negativno, a intelekt $\mathrm{i}$ optimizam pozitivno. Treba spomenuti da optimizam nije povezan s percepcijom pozitivnosti napretka. Logična je i međusobna povezanost dviju mjera percepcije budućnosti koja je umjereno pozitivna. Za međusobne povezanosti dimenzija intelekta i pesimizma/optimizma nema jasnih očekivanja kakve bi one bile (Sharpe, Martin i Roth, 2011). U skladu je s rijetkim podatkom o toj vezi (Lounsbury, Saudargas i Gibson, 2004), gdje je korelacija optimizma i dimenzije otvorenosti iznosila $r=.30$, i povezanost u ovom istraživanju. U kontekstu opaženih odnosa mjera ličnosti i mjera percepcije budućnosti te pretpostavljenih odnosa intelekta i optimizma/pesimizma od interesa može biti i (među)odnos mjera ličnosti (optimizma/pesimizma i intelekta) spram mjera percepcije budućnosti. Budući da je intelekt temeljna dimenzija ličnosti, moglo bi se pretpostaviti da je u povezanosti te dimenzije i percepcije budućnosti zapravo optimizam i pesimizam, kao mogući medijator veze. Kako bi to provjerili, radi jednostavnije je interpretacije provedena regresijska analiza.

Tablica 3.

Povezanosti između mjera ličnosti i mjera percepcije budućnosti

\begin{tabular}{lccccc}
\hline & 1. & 2. & 3. & 4. & 5. \\
\hline 1. percepcija poz. napretka & - & $.46^{* *}$ & $.20^{* *}$ & .14 & $-.18^{*}$ \\
2. percepcija budućnosti & & - & $.21^{* *}$ & $.35^{* *}$ & $-.28^{* *}$ \\
3. intelekt (IPIP) & & & - & $.36^{* *}$ & $-.41^{* *}$ \\
4. optimizam & & & & - & $-.73^{* *}$ \\
5. pesimizam & & & & & - \\
\hline
\end{tabular}

${ }^{*} p<.05 ;{ }^{* *} p<.01$.

Kada se u regresijski model prvo uvrsti intelekt, on statistički značajno predviđa varijancu mjere percepcije budućnosti $(\beta=.24, p<.01)$, no kada se u drugom koraku uvrsti optimizam i pesimizam, gdje samo optimizam dodatno statistički značajno predviđa kriterij $(\beta=.32, p<.01)$, intelekt u potpunosti gubi svoj doprinos, iz čega proizlazi da povezanost intelekta i percepcije budućnosti zapravo posredovan 
optimizmom (Sobelov test statističke značajnosti medijacije za optimizam: $z=2.74$, $p<.01$; za pesimizam $z=0.09, p>.05$ ). U slučaju mjere percepcije pozitivnosti napretka kako optimizam nije značajan prediktor ispitana je samo posredna veza pesimizma. Kada se u prvom koraku kao prediktor uvrsti intelekt, on statistički značajno predviđa kriterij $(\beta=.21, p<.05)$. Dodavanjem mjere pesimizma u drugom koraku, intelekt i dalje ostaje statistički značajan prediktor $(\beta=.15, p=.05)$, ali je taj doprinos umanjen, što bi upućivalo na to da je pesimizam djelomični medijator veze intelekta i percepcije pozitivnosti napretka. Međutim, u statističkom smislu medijacijski učinak nije bio značajan (Sobelov test statističke značajnosti medijacije $z=1.54, p>.05)$.

\section{Rasprava}

U doba industrijske revolucije ljudi su razbijali strojeve jer su smatrali da im oni uzimaju poslove i egzistenciju (Steven, 2006). Ipak, pokazalo se da su se ljudi civilizacijski uspjeli prilagoditi na tu veliku prekretnicu te da je ljudska populacija u velikoj mjeri profitirala od industrijalizacije. Iako nove tehnike donose različite perspektive dobrobiti i boljitka, postoji i opravdana sumnja i bojazan od opasnosti i rizika koje brz napredak tehnike može donijeti. Stoga je logično da dio populacije nije sklon tehničkim promjenama i ne vjeruje da će te promjene biti korisne ili poželjne. Ljudi su i u suvremenom kontekstu skeptični prema onim promjenama koje ne mogu posve razumjeti ili ih pak mogu doživjeti kao potencijalnu prijetnju načinu života kakvog poznaju. Podaci iz ovog istraživanja pokazuju da je izlaganje informacijama o budućnosti tehničkog razvoja imalo učinka i na afektivne, ali i kognitivne procjene, $\mathrm{i}$ to dominantno u negativnom smjeru.

Davanje različitih informacija, kako formom, tako i sadržajem o budućnosti dovela je do promjena kako u pozitivnom, tako i u negativnom afektu. Iako te promjene nisu velike, $u$ ovom se istraživačkom kontekstu mogu razumno objasniti. Pozitivni se afekt promijenio na višu razinu, i to samo kod skupine kojoj su bila prikazana znanstvena predviđanja. Naime, namjera tribine s predavanjem bila je dati sudionicima objektivne informacije o napretku tehnike te balansirano prenijeti moguće pozitivne i negativne posljedice takvog napretka, bez donošenja konačnih zaključaka o korisnosti tehničkog napretka. S druge strane, u seriji Black Mirror novi je izum prikazan u distopijskom svjetlu, bez usmjeravanja na moguće pozitivne posljedice izuma, stoga ne čudi što u toj skupini nije došlo do porasta u pozitivnom afektu. S druge strane, negativni se afekt promijenio kod obiju skupina, i to u istom (negativnijem) smjeru. Kako je i navedeno, obje su mjere afekta međusobno relativno nezavisne te ne bi trebalo čuditi nesuglasje da je izlaganje informacijama promijenilo obje mjere $\mathrm{u}$ istom smjeru "povećanja".

Ako se na rezultate o promjenama afektivnog stanja nadovežu rezultati koji su u domeni više spoznajnog procesiranja, gdje se mjera percepcije budućnosti najbolje 
može poistovjetiti s mjerenjem stavova tehnikom semantičkog diferencijala, a mjera percepcije pozitivnosti napretka reprezentira očekivanu korist od napretka tehnike, onda se može zaključiti da je prikazivanje različitih pogleda o budućnosti dovelo do promjena $\mathrm{u}$ negativnom smjeru. Percepcija budućnosti blago je negativna $u$ skupinama koje su bile izložene tretmanu predavanjem/filmom za razliku od referentne skupine, koja je ostala u području blago pozitivne percepcije. Sukladno tome jesu i rezultati na mjeri pozitivnosti percepcije napretka, gdje se pokazalo da se dvije tretmanske skupine ponovo razlikuju u odnosu na referentnu, i to tako da napredak percipiraju manje pozitivnim. Dodatno, veća je promjena u negativnom afektu kod obiju skupina bila umjereno i negativno povezana s percepcijom pozitivnosti napretka.

Izgleda da su i predavanje i SF prikaz budućnosti potaknuli sudionike na razmišljanje o temama o kojima možda prije i nisu previše promišljali, a koja se na neki način izravno tiču i njihove vlastite budućnosti, što je dovelo do promjena u afektivnim reakcijama. Sa stajališta mogućeg prilagođavanja ljudi na brze promjene koje razvoj nosi, afektivne su reakcije važne jer su dio emocionalnog korpusa, a emocije jedan od glavnih motivatora našeg ponašanja, utemeljen na biologiji i evoluciji. Ovo istraživanje pokazuje da se takve reakcije lako potaknu, i da njihovo djelovanje može biti pozitivno, ali i dominantno negativno, o tome ovisno kako se informacije prikazuju. Skowronski i Carlston (1989) također su pokazali da negativne informacije imaju veći značaj na stvaranje dojmova i očekivanja od pozitivnih informacija. Moguće je da zbog toga pozitivan vid budućnosti prezentiran u izlaganju o stvarnim predviđanjima budućnosti nije znatno povećao rezultate percepcije budućnosti i napretka tribinske skupine u odnosu na SF skupinu.

Budući da je vrlo vjerojatno da će se razvoj tehnike nastaviti, i to velikom brzinom, logično je pretpostaviti da su i sudionici ovog istraživanja imali takav implicitni stav o mogućim brzim promjenama. To posredno pokazuje i povezanost mjera percepcije budućnosti te percepcije pozitivnosti napretka tehnike koja pokazuje umjereno slaganje tih mjera i mjera ličnosti. Općenito, pozitivniju percepciju budućnosti i napretka imaju ljudi koji su optimističniji, manje pesimistični te imaju više izraženu osobinu intelekta. Ovi rezultati mogli bi se objasniti Kanazawinim načelom savane (2004). Taj evolucijski pristup objašnjava kako su mnogi problemi s kojima se ljudi susreću uzrokovani time što je naš mozak ostao nepromijenjen posljednjih desetak tisuća godina zbog prevelikih promjena u okolini koje su slijedile nakon toga te onemogućile daljnji evolucijski razvoj mozga. Budući da je ljudsko ponašanje još uvijek u velikoj mjeri prilagođeno na okolinu naših davnih predaka, to može dovoditi do poteškoća u funkcioniranju u modernom svijetu, ali i do problema u shvaćanju modernih koncepata. Hipoteza o interakciji načela savane $\mathrm{i}$ inteligencije pretpostavlja da bi pojedinci s višom inteligencijom trebali biti uspješniji u rješavanju evolucijski novih problema (onih koji nisu postojali u okolini naših dalekih predaka), te da će bolje razumijevanje evolucijski novih podražaja, omogućeno inteligencijom, voditi i većoj vjerojatnosti njegove 
preferencije. Naime, ako pojedinac nešto ne može razumjeti, to mu se vjerojatnije neće ni sviđati. To bi moglo objasniti relativno niske, ali pozitivne korelacije varijable ličnosti intelekta, odnosno optimizma i percepcija pozitivnosti budućnosti i napretka.

Kroz rezultate ovog istraživanje može se pretpostaviti potencijalni značaj medija na formiranje mišljenja ljudi o nekim aspektima budućnosti koja nam je pred vratima. Budući scenariji SF filmova mogli bi utjecati na formiranje općeg mnijenja o korisnosti i/ili opasnosti tehničkih izuma te bi to trebalo imati na umu. Trenutna je praksa filmskih kompanija da se u najvećem broju SF materijala budućnost prikazuje izuzetno distopijski, a trebalo bi promisliti stvara li to više štete ili koristi te je li potreban i paralelni, znanstveno utemeljen način kolektivnog promišljanja o budućnosti tehničkog razvoja, koji bi uravnoteženo prikazivao potencijalne pozitivne i negativne aspekte razvoja. Važno je pri tome obratiti pozornost na izvor koji se koristi u prenošenju znanstveno utemeljenih informacija o budućnosti (Briñol i Petty, 2009). Karakteristike izvora koje osobito utječu na stvaranje očekivanja u skladu s prezentiranim informacijama percipirana su vjerodostojnost $\mathrm{i}$ autoritet izvora. Vjerodostojnost je pojam koji označava percipiranu stručnost i pouzdanost izvora. $U$ ovom kontekstu, vjerodostojan bi izvor bio stručnjak iz područja računalnih znanosti, čija profesionalna pozicija i kvalifikacije odražavaju visoko razumijevanje budućnosti tehničkog razvoja. Briñol i Petty (2004) pokazali su da snaga argumenata igra važnu ulogu u persuaziji. Kada se prikažu snažni argumenti, veća je vjerojatnost promjene stava u željenom smjeru. Važno je i je li poruka usmjerena na proces mišljenja ili na izazivanje emocionalne reakcije (Petty i Briñol, 2015). Uspješnost prenošenja poruke ovisi i o komunikacijskom kanalu (Petty, 2018): kod kompleksnih je poruka informacije važno prikazati verbalno i pismeno, a potencijalno i slikovito (prezentacijom), kako bi se lakše procesuirale i dulje pamtile. Složene informacije, kakve su i one vezane uz tehnički razvoj, općoj populaciji treba prezentirati što jednostavnijim rječnikom, jer nerazumijevanje poruke dovodi do zbunjenosti slušača i formiranja nejasnih stavova o budućnosti i pozitivnosti tehničkog razvoja.

\section{Implikacija i ograničenja}

Ovo je istraživanje većinom bilo eksploratorno te nam može dati smjernice za daljnja istraživanja ove tematike. Sličnih istraživanja zapravo nema, te su i hipoteze ovog istraživanja bile prilično općenite, pa implikacije ne mogu biti sasvim eksplicitne. Unutarnja je valjanost istraživanja bila ugrožena samom prirodom nacrta i primijenjenog postupka. Primjerice, jedan je od faktora ugrožavanja bila nemogućnost slučajnog rasporeda sudionika u skupine. Ovome se probalo doskočiti jednakim pozivnim oglasom bez previše informacija o postupku za obje skupine, kako bi se sudionici slučajno u njih raspodijelili, a što možda i nije bio slučaj. Još jedan od problema koji proizlazi iz nacrta je i samoselekcija sudionika. Vjerojatno su na istraživanje odlučili doći oni ljudi koji su i inače više zainteresirani za tehničke i futurističke teme, a vjerojatno je i da su studenti dovodili sudionike koji su slični 
njima samima. Nejednak broj sudionika u dvije tretmanske skupine isto tako slabi unutarnju valjanost. Zbog načina je oglašavanja tribina bilo izvjesno da će na tribine doći većinom visokoobrazovani ljudi, tj. većinom studenti, što može imati implikacija na moguću generalizaciju rezultata na opću populaciju. Pretpostavka je autora da bi efekti opaženi u ovom istraživanju na uzorku koji bi bolje reprezentirao populaciji bili istog smjera, samo izraženiji.

Još jedan faktor ugrožavanja unutarnje valjanosti bila je potencijalna neujednačenost dviju eksperimentalnih skupina vezano uz eksperimentalnu manipulaciju. Predavanje o budućnosti temeljeno je na znanstvenim i tehničkim informacijama o trenutnom razvoju i znanstvenim predviđanjima, koje variraju od vrlo pozitivnih do vrlo negativnih. Primjerice, navedeno je da bi se razvoj umjetne inteligencije mogao koristiti u okviru medicine za razvoj novih metoda liječenja, znatno efikasnijih od današnjih metoda, ali i u kreaciji superoružja, znatno efikasnijih od današnjih oružja. Sudionicima su u okviru predavanja uravnoteženo prenijete moguće pozitivne i negativne posljedice takvog napretka, bez donošenja konačnih zaključaka o korisnosti tehničkog razvoja. U drugoj skupini, koja je gledala znanstvenofantastični prikaz (seriju Black Mirror), novi je izum prikazan u negativnom svjetlu, bez usmjeravanja na moguće pozitivne posljedice. Ovakva je neujednačenost $u$ dvije eksperimentalne skupine mogla utjecati na rezultate, stoga je potrebno dobivene rezultate interpretirati s oprezom. Odgovori na pitanja koja su bila u ciljevima ovog istraživanja važni su kako bi nam dali informaciju o tome kako će različiti ljudi reagirati kad se svijet kakav poznajemo počne mijenjati još brže. Kako će nam biti u takvoj budućnosti u velikoj mjeri ovisi o našoj sposobnosti kontinuirane prilagodbe na tehničke novitete te o našem suočavanju s etičkim dilemama koje se $u$ takvoj budućnosti pojavljuju. Rezultati ovog istraživanja pokazuju blagi trend negativne percepcije koji brz napredak može imati, a naročito u kontekstu kada su informacije o napretku dane u "zabavnom" filmu. Šira svrha ovog istraživanja leži i u poticanju što većeg broja ljudi na razmišljanje o tome što nam doista donosi budućnost, kao i poticanje promišljanja znanstvenih, praktičnih, ali i etičkih aspekata eksponencijalnog tehničkog razvoja. Jer uz manjkavu informiranost o "stvarnim" predviđanjima i promjenama, ljudi su svakodnevno izloženi velikoj količini različitih znanstvenofantastičnih prikaza budućnosti, ili pak pseudoznanstvenih iz dnevnog tiska. Te informacije mogu biti doživljene kao relevantne i nepoželjne te imati vezu s pojavom negativnih afektivnih stanja, ali i negativnijom percepcijom budućnosti, kao što su pokazali rezultati ovog istraživanja. A oni također pokazuju da su i individualne razlike u domeni ličnosti one koje mogu djelomično predviđati reakcije. Što su ljudi otvoreniji prema iskustvu, svijetu, to je veća mogućnost da će i promjene koje donosi brz tehnički razvoj biti bolje prihvaćene.

Šira svrha ovog istraživanja bila je i veća senzibilizacija opće populacije i znanstvene zajednice na promjene koje nas prema predviđanjima stručnjaka za tehniku očekuju u ne tako dalekoj budućnosti. Iako se stručnjaci ne slažu oko toga kakve će posljedice razvoj tehnike u budućnosti imati na nas, ljude, većinom se slažu 
oko neminovnosti skorih promjena, koje potvrđuju i matematički modeli. Zato je potrebno informirati širu javnost i pokrenuti akademske rasprave o ovom području kako bi se moglo razmatrati etičke implikacije i pripremiti se na neizbježne promjene koje donosi razvoj ovih područja. Upravo bi psiholozi, stručnjaci za psihičko zdravlje, trebali imati važnu ulogu u pomoći u prilagodbi cijele populacije na život u značajno drugačijoj okolini, u kojoj bi ljudi mogli biti okruženi robotima, kiborzima i umjetnom inteligencijom na razini ljudske. Je li napredak tehnologije dobar ili loš manje je važno pitanje, upravo zato jer su izuzetno male vjerojatnosti da bi se on mogao zaustaviti. Činjenica je da se on događa i eksponencijalno ubrzava te bi pravo pitanje trebalo biti - kako se najbolje prilagoditi na njega. Jedan je od mogućih odgovora proširenjem znanstvenog interesa za ove teme te provođenjem istraživanja koja bi nam mogla dati smjernice za postupanje u interesu bolje prilagodbe populacije na stanje u svijetu.

\section{Prijedlozi za buduća istraživanja}

Budući da je unutarnja valjanost ovog istraživanja bila ugrožena samom prirodom nacrta i potencijalnom neujednačenošću eksperimentalnih manipulacija, nije moguće eliminirati alternativna plauzibilna objašnjenja dobivenih efekata. U budućim bi istraživanjima bilo zanimljivo vidjeti kako bi sudionici procjenjivali pozitivnost budućnosti i napretka kad bi im bili prikazivani drugačiji filmovi. Podražajni materijal mogao bi se varirati po razini pozitivnosti budućnosti koja je prikazana, od izuzetno distopijske, preko relativno neutralne, do utopijske budućnosti. Također, zanimljivo bi bilo vidjeti utječe li na sudionike više film koji prikazuje blisku budućnost, koja im je relativno opipljiva, ili vrlo daleku budućnost, s pretpostavkom da će na njihova predviđanja budućnosti više utjecati prikaz bliske budućnosti. Predavanje o budućnosti također se može predstaviti u različitom emocionalnom tonu, od izuzetno negativnog do pozitivnog. Bilo bi zanimljivo vidjeti učinak različitih predavača na percepciju, u rasponu od predavača koji nema previše veze s područjem, do renomiranog (ili sudionicima poznatog) stručnjaka za tehnologiju. Još neke karakteristike ličnosti sudionika mogle bi imati značajne efekte na rezultate. $U$ ovom su istraživanju izabrane one za koje se pretpostavljalo da bi mogle imati određenu vezu, no osobine poput neuroticizma, anksioznosti, lokusa kontrole ili sklonosti katastrofiranju isto su tako plauzibilni kandidati u budućim istraživanjima, jer se pokazalo da je sklonost negativnijim očekivanjima sustavnije povezana s percepcijom budućih događaja. Nadamo se da će ovaj pionirski eksperiment potaknuti autore na daljnja i detaljnija istraživanja ovoga zanimljivog, relativno neistraženog, a izuzetno relevantnog područja za razumijevanje što bolje prilagodbe ljudi na budućnost, koju karakteriziraju brze promjene. 


\section{Literatura}

Bar, M. (2007). The proactive brain: Using analogies and associations to generate predictions. Trends in Cognitive Sciences, 11(7), 280-289.

Bar-Cohen, Y. i Hanson, D. (2009). The coming robot revolution: Expectations and fears about emerging intelligent, humanlike machines. NY: Springer Science \& Business Media.

Borup, M., Brown, N., Konrad, K. i Van Lente, H. (2006). The sociology of expectations in science and technology. Technology Analysis \& Atrategic Aanagement, 18(3-4), $285-$ 298.

Briñol, P. i Petty, R. E. (2004). Self-validation processes: The role of thought confidence in persuasion. U: G. Haddock i G. Maio (Ur.), Contemporary perspectives on the psychology of attitudes (str. 205-226). Philadelphia, PA: Psychology Press.

Briñol, P. i Petty, R. E. (2009). Source factors in persuasion: A self-validation approach. European Review of Social Psychology, 20(1), 49-96.

Bubić, A. i Abraham, A. (2014). Neurocognitive bases of future oriented cognition. Review of Psychology, 21(1), 3-15.

Chang, E. C. (2001). Optimism \& pessimism: Implications for theory, research, and practice. Washington DC: American Psychological Association.

Chang, E. C., Maydeu-Olivares, A. i D'Zurilla, J. (1997). Optimism and pessimism as partially independent constructs: Relationship to positive and negative affectivity and psychological well-being. Personality and Individual Differences, 23, 433-440.

Crawford, J. R. i Henry, J. D. (2004). The Positive and Negative Affect Schedule (PANAS): Construct validity, measurement properties and normative data in a large non-clinical sample. British Journal of Clinical Psychology, 43(3), 245-265.

Goldberg, L. R. (1999). A broad-bandwidth, public-domain, personality inventory measuring the lower-level facets of several five-factor models. U: I. Mervielde, I. J. Deary, F. De Fruyt i F. Osterndorf (Ur.), Personality psychology in Europe (Vol. 7, str. 7-28). Tilburg: Tilburg University Press.

Herzberg, P. Y., Glaesmer, H. i Hoyer, J. (2006). Separating optimism and pessimism: A robust psychometric analysis of the Revised Life Orientation Test (LOT-R). Psychological Assessment, 18, 433-438.

Kanazawa, S. (2004). The savanna principle. Managerial and Decision Economics, 25(1), 41-54.

Kirsch, I. (1985). Response expectancy as a determinant of experience and behavior. American Psychologist, 40(11), 1189-1202.

Konrad, K. (2006). The social dynamics of expectations: The interaction of collective and actor-specific expectations on electronic commerce and interactive television. Technology Analysis \& Strategic Management, 18(3-4), 429-444. 
Kurzweil, R. (2005). The singularity is near: When humans transcend biology. New York: Penguin Books.

Lounsbury, J. W., Saudargas, R. A. i Gibson, L. W. (2004). An investigation of personality traits in relation to intention to withdraw from college. Journal of College Student Development, 45(5), 517-534.

Mancini, C., Rogers, Y., Bandara, A. K., Coe, T., Jedrzejczyk, L., Joinson, A. N., Price, B., Thomas, K. i Nuseibeh, B. (2010). Contravision: Exploring users' reactions to futuristic technology. U: Proceedings of the SIGCHI Conference on Human Factors in Computing Systems (str. 153-162). Atlanta Georigia.

Mlačić, B. i Goldberg, L. R. (2007). An analysis of cross-cultural personality inventory: The IPIP Big-Five factor markers in Croatia. Journal of Personality Assessment, 88(2), 168177.

Peerdeman, K. J., van Laarhoven, A. I. M., Peters, M. L. i Evers, A. W. M. (2016). An integrative review of the influence of expectancies on pain. Frontiers in Psychology, 7, 1270 .

Penezić, Z. (2002). Skala optimizma-pesimizma (OP skala). Zbirka psihologijskih skala $i$ upitnika (str. 15-17). Zadar: Filozofski fakultet.

Perkins, K. A., Karelitz, J. L., Conklin, C. A., Sayette, M. A. i Giedgowd, G. E. (2010). Acute negative affect relief from smoking depends on the affect situation and measure but not on nicotine. Biological Psychiatry, 67(8), 707-714.

Persson, I. i Savulescu, J. (2012). Unfit for the future: The need for moral enhancement. Oxford: Oxford University Press.

Petty, R. E. (2018). Attitudes and persuasion: Classic and contemporary approaches. NY: Routledge.

Petty, R. E. i Briñol, P. (2015). Emotion and persuasion: Cognitive and meta-cognitive processes impact attitudes. Cognition and Emotion, 29(1), 1-26.

Pezzulo, G., Hoffmann, J. i Falcone, R. (2007). Anticipation and anticipatory behavior. Cognitive Processing, 8, 67-70.

Rozin, P. i Royzman, E. B. (2001). Negativity bias, negativity dominance, and contagion. Personality and Social Psychology Review, 5(4), 296-320.

Schaller, R. R. (1997). Moore's law: Past, present and future. Spectrum, IEEE, 34(6), 52-59.

Schwarz, K. A., Pfister, R. i Büchel, C. (2016). Rethinking explicit expectations: Connecting placebos, social cognition, and contextual perception. Trends in Cognitive Sciences, 20(6), 469-480.

Selak, M. (2013). Ljudska priroda i nova epoha. Zagreb: Naklada Breza.

Sharpe, J. P., Martin, N. R. i Roth, K. A. (2011). Optimismand the Big Five factors of personality: Beyond Neuroticsm and Extraversion. Personality and Individual Differences, 51, 946-951.

Skowronski, J. J. i Carlston, D. E. (1989). Negativity and extremity biases in impression formation: A review of explanations. Psychological Bulletin, 105, 131-142. 
Steven, E. J. (2006). Against technology: From the luddites to neo-luddism. NY: Routledge Taylor \& Francis Group.

Stewart, H. (2015). Robot revolution: Rise of 'thinking' machines could exacerbate inequality. The Guardian. Preuzeto s https://www.theguardian.com/technology/2015/nov/05/ robot-revolution-rise-machines-could-displace-third-of-uk-jobs

Van Lente, H. (2012). Navigating foresight in a sea of expectations: Lessons from the sociology of expectations. Technology Analysis \& Strategic Management, 24(8), 769782.

Watson, D. (2000). Mood and temperament. New York: Guilford Press.

Watson, D. i Clark, L. A. (1988). Development and validation of brief measures of positive and negative affect: The PANAS scales. Journal of Personality and Social Psychology, 54, 1063-1070.

Zuckerman, M. (2003). Optimism and pessimism: Biological fondation. U: E. C. Chang i L. J. Sanna (Ur.), Virtue, vice, and personality: The complexity of behavior (str. 169-188). Washington DC: American Psychological Association.

\title{
Future Scenarios - Affective and Cognitive Responses to Information about the Future and Technical Development
}

\begin{abstract}
The aim of this research was to examine the cognitive and affective reactions of people to the information about rapid technical development which will, according to Moore's law and predictions of computer science specialists, be speedily accelerated and extended to all domains of human life in the near future. It is questionable whether people are ready for these changes and how would they react on them, both from an affective and a cognitive point of view. The study involved three groups of participants $(N=197)$. The first received information on the future of technical development based on scientific predictions and thoughts of authority through the carefully planned lecture. The other group received implicit information on possible changes connected with rapid development by displaying a science fiction film. The third group was referential - participants did not receive any information. The data on the perception of the future and of the positivity of progress were collected in all three groups. The results showed that the groups that were exposed to information about the future systematically assessed the future more negatively than the reference group. These differences were statistically significant but relatively small. Some of the stable characteristics of the personality domain, such as optimism and the dimension of intellect, have been shown to be slightly positively associated with the perception of the future. The results imply the importance of interdisciplinary academic discussions on the potential impact of the rapid development of technology on people's lives to facilitate the adjustment of people to such development.
\end{abstract}

Keywords: technology, future, development, progress

Primljeno: 3.7.2018. 